\title{
Illumination Conditions and Visual Comfort in Production Spaces of Ready-Made Garments Factories in Dhaka
}

\author{
Md Mohataz Hossain and Khandaker Shabbir Ahmed
}

\begin{abstract}
In Bangladesh, Ready-made garment (RMG) sector is fully supported by the workers who labour in the production spaces of garments factory buildings throughout the day. Appropriate Illumination conditions of these production spaces, which indicate the quality as well as quantity of lighting suitable for the production processes, is a major requirement. As indoor environments of these spaces are becoming highly complex, working under poor lighting conditions are usually exposed to a variety of visual problems with operating machines, textile sewing activities, ironing and other tasks. Visual comfort for various illumination levels has impact on total physical comfort condition and any physical discomfort influences the human behaviour and their works. Eventually, the visual comfort of these workers becomes a significant issue which is based upon determining the suitable range of illumination levels and glares available on the work plane of the user. Local visual comfort standards and guidelines for improving the illumination conditions in these production spaces should be established for incorporation in the sustainable design process. The objective of this paper is to investigate standard illumination conditions in terms of visual comfort of the workers in production spaces of RMG sector of Dhaka region. .
\end{abstract}

Index Terms-Illumination condition, production space, ready-made garments, visual comfort.

\section{INTRODUCTION}

Among the environmental compliances in Bangladesh, recommended Illumination condition in RMG sector is one of them that must be ensured. The illumination condition includes the quality as well as quantity of the lighting. But in the production space (Sewing, Cutting, dyeing and finishing), harmful human health impacts can result from poor environmental quality inside buildings [1]. In addition, poorly designed and maintained lighting systems can result in glare and flicker that may cause vision problems. Appropriate quantities of light are essential, but quality issues are just as important in providing a comfortable and safe working atmosphere. When the lighting meets the needs, it adds better working performance and productivity [2]. Therefore, appropriate illumination conditions should be maintained not only for the visual comfort of the workers but also for effective production in the RMG sectors.

While considering the human factor in luminous environment, visual comfort comes first and it can be described by the concepts of glare and contrast. Glare is usually caused by high luminances or excessive luminance differences in the visual field. Hence, most of the researches

Manuscript received March 15, 2013; revised June 19, 2013

The authors are with the Department of Architecture, Bangladesh University of Engineering and Technology, Dhaka -1000, Bangladesh (e-mail: mohataz@arch.buet.ac.bd,saa@optimaxbd.net). in measuring the visual comfort of human being have been based upon determining the range of illumination levels available on the work plane (Fig. 1) [3]. Visual performance can be improved with increasing luminance. But there is a plateau above which further increases in luminance do not lead to improvements in visual performance [4], [5]. Thus increasing luminance levels above the optimum for visual performance may not be justified and can on the contrary lead to excessive use of energy.

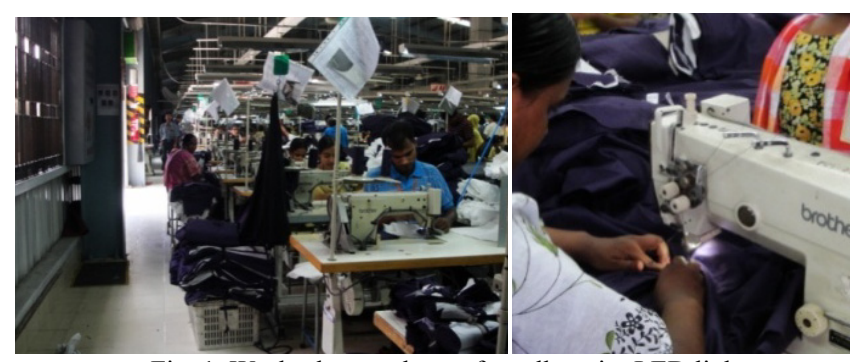

Fig. 1. Work-plane and use of needle point LED light

In order to explore possible physiological impact of the luminous environment reported health issues can be considered. The main health issues of the garments workers include incidence of illness, reasons for taking leave, occupational safety and health among others [6] which are the indicators of inappropriate illumination and related conditions. In Fig. 2, among the illness and diseases, Eye pain and headache were notable issues in the record of 2003 considering average duration of suffering. Across job categories, sewing operators, finishing helpers and quality controllers were found to suffer most from the eye troubles (Fig. 2). As the workers under these categories do more critical jobs which need adequate lighting environment, inappropriate lighting condition may cause the above vision problems including eye pain [6].
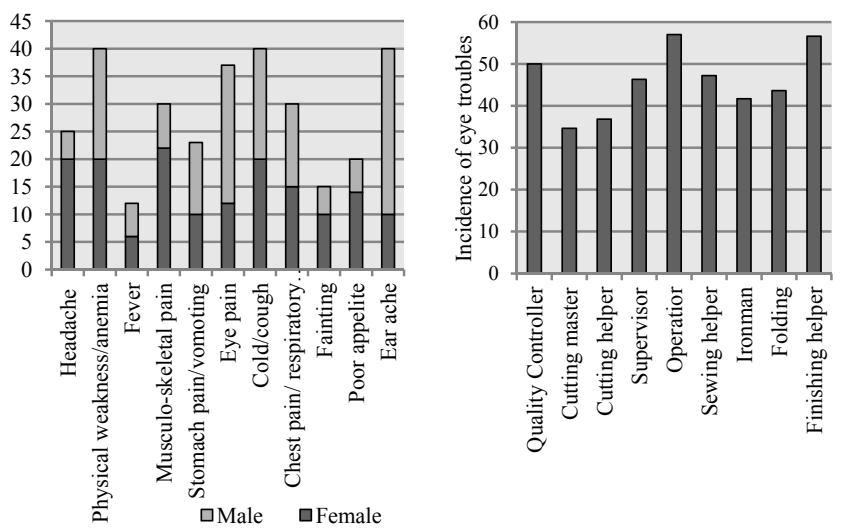

Fig. 2. Health issues in terms of duration and workers with eye problem

Task lighting in the industrial buildings for RMG is not dimmable. Some factories use needle point lighting (with 
LED task lighting) for achieving the illumination level at the work plane (Fig. 1). But considering the brightness ratio at the work environment, this solution conflicts with the quality lighting environment and may cause visual problems of the operator. Most of activities here are labour intensive, demands operating environment with adequate lighting for efficiency. Therefore it is necessary to maintain an excellent work environment for maximizing productivity [7]. If luminous environments are not given due consideration by the designer while locating and selecting the type of artificial lights and daylight penetration in the building envelop, it will increase the overall national electrical energy demand.

\section{OBJeCtive}

The objectives of this research are to investigate standard illumination levels and conditions for optimum visual comfort of the RMG workers in the production spaces and to generate recommended illumination conditions for the production spaces that would be useful to have maximum work efficiency in context of Dhaka region.

\section{Methodology}

Field surveys were conducted with detailed experimental study of the selected RMG production spaces on illumination conditions and feedback of the workers from factories in Dhaka region. According to Bangladesh Garments Manufacturers and Exporters Association (BGMEA) directory about 2000 member factories are in Dhaka and its adjacent regions. About 100 factories were shortlisted randomly. After structuring the initial questionnaire, a limited number of purpose built factories from the shortlist have been earmarked randomly on the basis of some selection criteria guided by BGMEA in Dhaka region for the pilot survey as a reconnaissance survey in order to explore the space-geometry and typologies of the production spaces of garments factories in this region. Three typical example of production units of three different factories were then selected for detailed investigation of the respective luminous environment and workers' visual comfort evaluation. The production spaces were varying in shape including different ceiling heights and types, depth of production unit, window height, lighting layout and other relevant features. These factors were identified in the pilot survey. The RMG Factory buildings, with production unit number one, two and three, are nine, two and six storied respectively. Among them detailed structured surveys were conducted at different levels of the factory building to investigate the existing illumination conditions of the production spaces.

While selecting the sample size for visual comfort evaluation, MSc work, done by Proma [8] was considered, where survey was conducted on garments factory workers in Bangladesh to study the work compatibility of the workers. The sample size of this research was 60 . According to this research, sample of 60 workers was chosen from each of three production spaces for detail questionnaire study as well as statistical analysis. The initial number of variables of this total research was 19 of which 13 were independent variables and 6 were dependent variables. But this paper only reflects on the correlation between the dependent variable (workers' feedback in terms of visual comfort) and some other significant independent variable related to illumination condition. However, the other independent variables were observed in the total population of the production spaces to assign them in a constant group. Final selection of 60 sample workers was done from their evaluation sheets or indexes. But all personal data are input variable or constant. The rest of the data were collected directly from the worker's working area through consultation, observation and measured by light meter. Criteria of the samples were determined by making same age group and work type constant to limit the scope of work. Thus, the results on workers evaluation gained through intensive field survey applies to the sewing workers, both male and female, whose age group is around 18-25 years in common and who have experiences from 1 month to over 2 years with an average 9-10 working hours per day. Worker's feedback of the comfort was collected by some convenient numeric scales $(-2$ to +2$)$ at the same time to quantify the levels of some parameters related to visual performance (adequacy of light, brightness, contrast, glare and eye problem).

\section{EXISTING ILLUMINATION CONDITION}

It was observed that the illumination level in production space type- 3 is a bit higher than the other spaces. The main reason behind it can be the overall artificial lighting layout, higher window lintel height which was observed only in this production space, location of the windows, outdoor illumination level, depth of the production space and any other features related to luminous environment (Table I). But variation (uniformity ratio) of the lighting levels was also observed in this production space.

TABLE I: Illumination LEVEL MEASURED AT WORK Plane IN PRODUCTION SPACES

\begin{tabular}{|c|c|c|c|}
\hline$\tilde{5}+$ & Location or zone & $\begin{array}{l}\text { Average Illumination } \\
\text { level with only } \\
\text { Daylight (Lux) } \\
\end{array}$ & $\begin{array}{c}\text { Average Illumination level } \\
\text { with Daylight and Artificial } \\
\text { Light (Lux) }\end{array}$ \\
\hline \multirow{3}{*}{ 䓌 } & $\begin{array}{l}\text { Near window (Party } \\
\text { Daylight) }\end{array}$ & 166 & 873 \\
\hline & $\begin{array}{l}\text { Centre of the half depth of } \\
\text { space (Mostly Artificial } \\
\text { Lighting) }\end{array}$ & 3 & 588 \\
\hline & $\begin{array}{l}\text { Furthest from Windows } \\
\text { (Completely artificial } \\
\text { Lighting) }\end{array}$ & 0 & 532 \\
\hline \multirow{3}{*}{$\begin{array}{l}\text { D } \\
\text { 苟 }\end{array}$} & Near window & 258 & 953 \\
\hline & $\begin{array}{l}\text { Centre of the half depth of } \\
\text { space }\end{array}$ & 9 & 672 \\
\hline & Furthest from Windows & 1 & 581 \\
\hline \multirow{3}{*}{$\stackrel{m}{\stackrel{*}{5}}$} & Near window & 287 & 1088 \\
\hline & $\begin{array}{l}\text { Centre of the half depth of } \\
\text { space }\end{array}$ & 6 & 792 \\
\hline & Furthest from Windows & 0 & 696 \\
\hline
\end{tabular}

TABLE II: AVERAGE UNIFORMITY, DIVERSITY AND SHR

\begin{tabular}{|l|l|l|l|}
\hline & \multicolumn{1}{|c|}{ Unit 1} & \multicolumn{1}{c|}{ Unit 2} & \multicolumn{1}{c|}{ Unit 3} \\
\hline $\begin{array}{l}\text { Uniformity of } \\
\text { Luminance }\end{array}$ & $\begin{array}{l}(435 / 664)= \\
0.66\end{array}$ & $\begin{array}{l}(420 / 735)= \\
0.57\end{array}$ & $\begin{array}{l}(390 / 805)= \\
0.48\end{array}$ \\
\hline Diversity of Illuminance & $\begin{array}{l}(1150 / 435) \\
=2.5: 1\end{array}$ & $\begin{array}{l}(1050 / 420) \\
=2.5: 1\end{array}$ & $\begin{array}{l}(1490 / 390) \\
=3.5: 1\end{array}$ \\
\hline Average $\mathrm{H}_{\mathrm{m}}(\mathrm{m})$ & 1.37 & 1.37 & 1.37 \\
\hline $\begin{array}{l}\text { Average Spacing } \mathrm{S}(\mathrm{m}) \\
=(\mathrm{a}+\mathrm{b}) / 2 \text { or } \sqrt{\mathrm{A} / \mathrm{N}}\end{array}$ & $\begin{array}{l}\sqrt{(2000 / 1128)} \\
=1.28\end{array}$ & $\begin{array}{l}(1.8+2.134) / 2 \\
=1.98\end{array}$ & $\begin{array}{l}(1.2+2.34) / 2 \\
=1.75\end{array}$ \\
\hline $\begin{array}{l}\mathrm{SHR}=\mathrm{S} / \mathrm{H}_{\mathrm{m}}(\text { linear } \\
\text { arrangement })=\end{array}$ & & & \\
$\left(1 / \mathrm{H}_{\mathrm{m}}\right) \sqrt{\frac{A}{N}}$ & 0.93 & $\begin{array}{l}1.44 \\
\text { (Linear }\end{array}$ & $\begin{array}{l}1.25 \\
\text { (Linear } \\
\text { arrangement) }\end{array}$ \\
$\begin{array}{l}\text { (rectangular } \\
\text { arrangement) }\end{array}$ & arrangement) & arrangement) & \\
\hline
\end{tabular}


While considering only daylight in the production spaces and uniformity ratio, it can be easily observed that the uniformity ratio of daylight is very low in all the production spaces. Hence, supportive artificial lights are installed in the indoor spaces. Uniformity of luminance, Diversity of Illuminance and Spacing Height Ratio were calculated based on recorded illuminances and other records during the surveys in the production spaces. 'Table II' reveals 'uniformity of luminance' of 0.48 in production space-3 which is considered to be low. The diversity of Illuminance at the work planes was also found high in production space-3. The workers of the production space- 3 may face more glare or contrast problem than other production spaces. The value of SHR is low in the production space- 1 which indicates good and glare-free artificial lighting environment.

The illumination level comparison in terms of nationally and internationally accepted practices and standards show that in the surveyed cases the highest levels are reached in the work planes, though international standards require less lighting in the work plane [9]. The usually recommended uniformity of luminance should not be less than 0.8 . But none of the production spaces met this standard. On the other hand, while considering the diversity of Illuminance, all the results were within the standard of $5: 1$.

\section{ANALYSIS AND RESULTS}

\section{A. Visual Comfort and Workers' Feedback Scenario}

Before going to analyse the correlation between the concerned variables, the user feedbacks observed in the field survey can be shown in the following diagrams (Fig. 3 and Fig. 4).
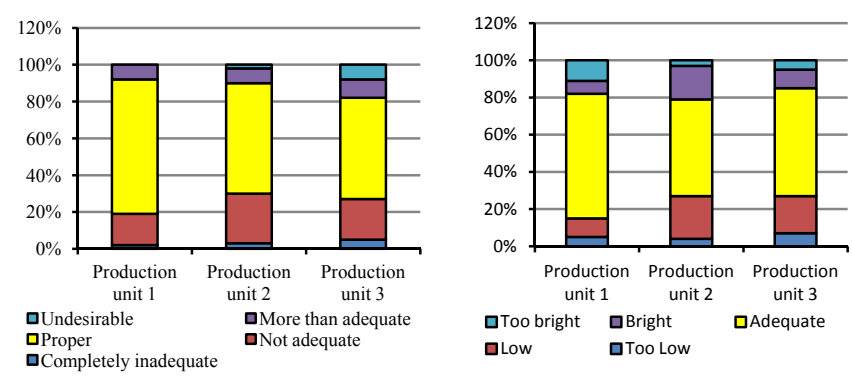

Fig. 3. Feedback of sample workers on adequacy of light and brightness
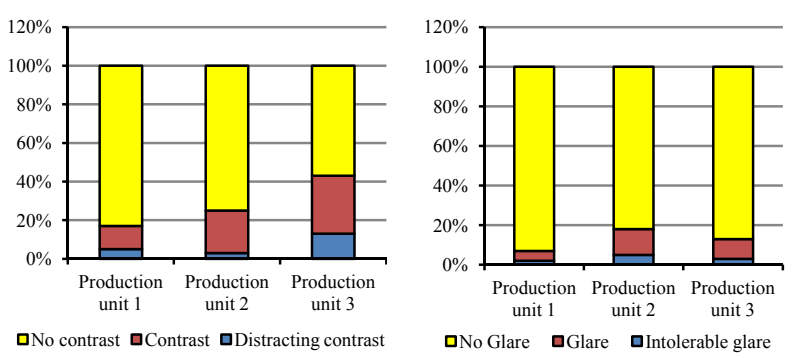

Fig. 4. Feedback of sample workers on contrast and glare

Among the samples, majority of them expressed that the adequacy of lighting condition is proper to do their sewing related works at their work plane, especially in production space-1 (73\%). On the other hand, while asking about the brightness, majority of them said that the brightness is adequate to do their works at their work plane, especially in production space $1(67 \%)$. Again, among the samples, majority of them said that the there was no contrast between the immediate surroundings and at their work plane, especially in production space 1 and $2(83 \%$ and $75 \%$ respectively). On the other hand, while asking about the Glare, majority of them said that there was no glare at their work station, especially in production space 1 and 3 (93\% and $82 \%$ respectively). The overall feedback from the worker shows that more than $50 \%$ of workers were comfortable with the illumination condition at their work plane.

\section{B. Worker's Feedback and Production Defects}

Even as carrying out statistical data analysis (Table III) to observe correlations among the variables of worker feedback (Lighting Adequacy, Brightness, Contrast between work plane and immediate surroundings, Glare from the Source of light, Eye Problem) and other output variable: number of Errors per hour (\%) [9], limited degree negative correlation were found between Lighting adequacy, Brightness, number of Errors per hour (\%) in production spaces [9].

TABLE III: CORRELATION BETWEEN WORKERS' FEEDBACKS AND PRODUCTION DEFECTS

\begin{tabular}{|c|c|c|c|c|c|}
\hline $\begin{array}{l}\text { Pro. } \\
\text { Unit } \\
\end{array}$ & Variables & $\begin{array}{c}\text { Lighting } \\
\text { Adequacy }\end{array}$ & Brightness & Contrast & $\begin{array}{c}\text { Number of } \\
\text { Errors per hr }\end{array}$ \\
\hline \multirow{4}{*}{ Unit 1} & $\begin{array}{l}\text { Lighting } \\
\text { Adequacy }\end{array}$ & 1.000 & & & \\
\hline & Brightness & 0.591 & 1.000 & & \\
\hline & Contrast & 0.261 & 0.046 & 1.000 & \\
\hline & $\begin{array}{l}\text { Number of } \\
\text { Errors per hr }\end{array}$ & -0.472 & -0.414 & -0.393 & 1.000 \\
\hline \multirow{4}{*}{ Unit 2} & $\begin{array}{l}\text { Lighting } \\
\text { Adequacy }\end{array}$ & 1.000 & & & \\
\hline & Brightness & 0.807 & 1.000 & & \\
\hline & Contrast & 0.467 & 0.317 & 1.000 & \\
\hline & $\begin{array}{l}\text { Number of } \\
\text { Errors per hr } \\
\end{array}$ & -0.539 & -0.578 & -0.221 & 1.000 \\
\hline \multirow{4}{*}{ Unit 3} & $\begin{array}{l}\text { Lighting } \\
\text { Adequacy }\end{array}$ & 1.000 & & & \\
\hline & Brightness & 0.787 & 1.000 & & \\
\hline & Contrast & 0.589 & 0.578 & 1.000 & \\
\hline & $\begin{array}{l}\text { Number of } \\
\text { Errors per hr }\end{array}$ & -0.530 & -0.525 & -0.448 & 1.000 \\
\hline
\end{tabular}

The correlation coefficients ( $\mathrm{r}$ values) between adequacy of lighting, brightness and production defects (\%) in production spaces reveal that increasing the brightness and adequacy lead to a decrease in production defects. But again, considering the scale range of the brightness and adequacy ( -2 to +2 which expresses 'too low brightness'/'completely inadequate' to 'too bright'/'undesirable'), it was found that there should be a range of illumination level (or brightness) within which production defects could be less. Limited degree negative correlations were also found between contrast and number of Errors per hour (\%) in production space 1 and 3 and the coefficients were 0.4 for both of the spaces. The above analysis revealed that user comfort reflects effective production with low number of defects.

\section{Illumination Condition to Observe Worker's Feedback}

While carrying out statistical data analysis (Table IV) to observe correlation among the variables of luminous data and worker-feedback data (Lighting Adequacy, Brightness, Contrast between work plane and immediate surroundings, Glare from the source of light, eye problem, number of errors per hr (\%), illumination level at work plane and Lighting Environment), some limited degree of positive correlations 
were found between lighting adequacy, brightness, contrast, glare and illumination level at work plane (\%), lighting environment. Moreover, limited degree negative correlations among the feedback data (lighting adequacy, brightness, contrast, glare and eye problem) were gained as well.

While focusing on only the illumination level (Table IV), coefficients showed that workers feedback about the brightness and adequacy increased with increasing the illumination level. But the unit/scale range for getting feedback data of the brightness and adequacy was from -2 to +2 which expresses 'too low brightness'/'completely inadequate' to 'too bright'/'undesirable'. So the above coefficients also meant that while illumination level was increasing, their comfort was also hampered after certain level as illumination level was more than their requirement. So there is a threshold above and below which their comfort level is affected. It could remain constant for a while before being affected. Now, focusing on the lighting level, coefficient showed that worker's feedback level on lighting adequacy increased with movement of their lighting environment or zone towards the natural light. Also there must be a threshold of the daylight penetration near to the work-plane as well. Some limited degree of positive or negative correlations were also observed only among feedback data which were very obvious given the situations and were highlighted in the Table IV. Some special cases of correlations were also observed in the production spaces no. 2 and 3. While increasing the lighting level at work plane in the production space 2 and 3, contrast between work plane and immediate surroundings also decreases (scale was set from -2 to 0 which meant 'distracting contrast' to 'no contrast'). In the production space 3 , correlation coefficients among contrast, glare, illumination level and lighting environment revealed that increasing the illumination level and moving the workers position towards the window also solves the contrast or glare problem (scale was set from -2 to 0 which meant 'distracting contrast'/ 'intolerable glare' to 'no contrast'/'no glare').

TABLE IV: CORRELATION AMONG ILLUMINATION AND WORKERS' FEEDBACK

\begin{tabular}{|c|c|c|c|c|c|c|c|}
\hline Pro. Unit & Variables & $\begin{array}{l}\text { Lighting } \\
\text { Adequacy }\end{array}$ & Brightness & Contrast & Glare & $\begin{array}{c}\text { Illumination } \\
\text { level }\end{array}$ & Lighting Environment \\
\hline \multirow{6}{*}{ Unit 1} & Lighting Adequacy & 1.000 & & & & & \\
\hline & Brightness & 0.591 & 1.000 & & & & \\
\hline & Contrast (between work plane and immediate surroundings) & 0.261 & 0.046 & 1.000 & & & \\
\hline & Glare (from Source of light) & -0.328 & -0.25 & -0.01 & 1.000 & & \\
\hline & Illumination level (at work plane) & 0.728 & 0.717 & 0.240 & -0.22 & 1.000 & \\
\hline & Lighting Environment & 0.392 & 0.214 & 0.363 & 0.005 & 0.450 & 1.000 \\
\hline \multirow{6}{*}{ Unit 2} & Lighting Adequacy & 1.000 & & & & & \\
\hline & Brightness & $\mathbf{0 . 8 0 7}$ & 1.000 & & & & \\
\hline & Contrast (between work plane and immediate surroundings) & 0.467 & 0.317 & 1.000 & & & \\
\hline & Glare (from Source of light) & 0.132 & 0.088 & 0.063 & 1.000 & & \\
\hline & Illumination level (at work plane) & 0.797 & 0.716 & 0.542 & 0.009 & 1.000 & \\
\hline & Lighting Environment & 0.690 & 0.520 & 0.252 & 0.023 & 0.680 & 1.000 \\
\hline \multirow{6}{*}{ Unit 3} & Lighting Adequacy & 1.000 & & & & & \\
\hline & Brightness & 0.787 & 1.000 & & & & \\
\hline & Contrast (between work plane and immediate surroundings) & 0.589 & 0.578 & 1.000 & & & \\
\hline & Glare (from Source of light) & -0.539 & -0.524 & -0.19 & 1.000 & & \\
\hline & Illumination level (at work plane) & 0.749 & 0.630 & 0.652 & -0.49 & 1.000 & \\
\hline & Lighting Environment & 0.663 & 0.547 & 0.603 & -0.24 & 0.591 & 1.000 \\
\hline
\end{tabular}

Observing all the coefficients between the variables of environmental data and worker-feedback data, it was quite clear that the surveyed feedback data (comfort data) categorically represents the relationship between their visual comfort and the illumination condition at their work-plane. From the worker feedback data collection the illumination levels, for which sample workers gave 'proper light' feedback, were identified and the specific number of samples that gave above feedback were 44, 36 and 33 in production units 1, 2 and 3 respectively. 'Table V' with the short listed illumination level ranges and feedback data on frequency of lighting explained that for production unit 1 and 2, the most desirable or proper lighting level ranges for workers' visual comfort in terms of brightness was 601 800 lux, while for production unit 3 , the range was $401 \sim 800$ lux. The summary (Table VI) gives the mean, maximum and minimum values of those illumination levels ranges at the work plane of short listed sample workers that gave 'proper lighting' as a feedback or comfort vote.
TABLE V: FREQUENCY OF ONLY THOSE LIGHTING LEVELS AGAINST WHICH SAMPLE WORKERS GAVE 'PROPER LIGHTING' AS A FEEDBACK

\begin{tabular}{cccc}
\hline $\begin{array}{c}\text { Bin Range (Illumination } \\
\text { Level, Lux) }\end{array}$ & $\begin{array}{c}\text { Frequency } \\
\text { (pro. unit 01) }\end{array}$ & $\begin{array}{c}\text { Frequency } \\
\text { (pro. unit 02) }\end{array}$ & $\begin{array}{c}\text { Frequency } \\
\text { (pro. unit 03) }\end{array}$ \\
\hline $0 \sim 200$ & 0 & 0 & 0 \\
\hline $201 \sim 400$ & 0 & 0 & 1 \\
\hline $\mathbf{4 0 1 \sim 6 0 0}$ & 8 & 7 & $\mathbf{1 0}$ \\
\hline $\mathbf{6 0 1 \sim 8 0 0}$ & $\mathbf{2 1}$ & $\mathbf{2 3}$ & $\mathbf{1 0}$ \\
\hline $\mathbf{8 0 0 \sim 1 0 0 0}$ & $\mathbf{1 4}$ & $\mathbf{6}$ & 9 \\
\hline $1101 \sim 1200$ & 1 & 0 & 1 \\
\hline More & 0 & 0 & 2 \\
\hline
\end{tabular}

TABLE VI: DESCRIPTIVE StATistics OF PROPER ILLUMinATION LEVEL RANGES ACCORDING TO THE WORKERS FEEDBACK SURVEY

\begin{tabular}{|c|c|c|c|}
\hline & Pro. unit 01 & Pro. unit 02 & Pro. unit 03 \\
\hline Mean & $\mathbf{7 5 0 . 0}$ & $\mathbf{6 9 6 . 5}$ & $\mathbf{7 6 3 . 2}$ \\
\hline Standard Deviation & 144.0 & 112.9 & 240.9 \\
\hline Minimum & $\mathbf{4 5 0 . 0}$ & $\mathbf{4 3 0 . 0}$ & $\mathbf{3 9 0 . 0}$ \\
\hline Maximum & $\mathbf{1 1 5 0 . 0}$ & $\mathbf{9 4 0 . 0}$ & $\mathbf{1 4 9 0 . 0}$ \\
\hline Count & 44.0 & 36.0 & 33.0 \\
\hline
\end{tabular}


From the field data on worker response the illumination levels, for which sample workers gave 'adequate brightness' feedback, were identified and the specific number of samples that gave the above feedback were 40,31 and 35 in the production units 1, 2 and 3 respectively. On the other hand, table with the short listed illumination level ranges and frequency data explained that for production unit 1 and 2 , the most desirable lighting level ranges for workers' visual comfort in terms of brightness was 601 800 Lux, while for production unit 3 , the range was within $401 \sim 600$ Lux. The summary (Table VIII) gives the mean, maximum and minimum values of those illumination levels ranges at the work plane of short listed sample workers that gave 'adequate brightness' as a feedback.

TABLE VII: FREQUENCY OF ONLY THOSE LIGHTING LEVELS AGAINST WHICH SAMPLE WORKERS GAVE 'ADEQUATE BRIGHTNESS' AS A

\begin{tabular}{cccc}
\hline $\begin{array}{c}\text { Bin Range (Illumination } \\
\text { Level, Lux) }\end{array}$ & $\begin{array}{c}\text { Frequency } \\
\text { (pro. unit 01) }\end{array}$ & $\begin{array}{c}\text { Frequency } \\
\text { (pro. unit 02) }\end{array}$ & $\begin{array}{c}\text { Frequency } \\
\text { (pro. unit 03) }\end{array}$ \\
\hline $0 \sim 200$ & 0 & 0 & 0 \\
\hline $201 \sim 400$ & 1 & 0 & 1 \\
\hline $\mathbf{4 0 1 \sim 6 0 0}$ & 9 & 7 & $\mathbf{1 3}$ \\
\hline $\mathbf{6 0 1 \sim 8 0 0}$ & $\mathbf{1 9}$ & $\mathbf{2 2}$ & $\mathbf{9}$ \\
\hline $\mathbf{8 0 0 \sim 1 0 0 0}$ & 11 & 2 & 9 \\
\hline $1101 \sim 1200$ & 0 & 0 & 2 \\
\hline More & 0 & 0 & 1 \\
\hline
\end{tabular}

TABLE VIII: DESCRIPTIVE STATISTICS OF ADEQUATE ILLUMINATION LEVEL RANGES IN TERMS OF BRIGHTNESS ACCORDING TO THE WORKERS

\begin{tabular}{|c|c|c|c|}
\multicolumn{5}{c|}{ FEEDBACK SURVEY } \\
\hline Mean & Unit 01 & Unit 02 & Unit 03 \\
\hline Standard Deviation & $\mathbf{7 1 2 . 9}$ & $\mathbf{6 7 5 . 4}$ & $\mathbf{7 3 3 . 1}$ \\
\hline Minimum & 133.6 & 95.2 & 228.9 \\
\hline Maximum & $\mathbf{3 8 0 . 0}$ & $\mathbf{4 7 0 . 0}$ & $\mathbf{3 9 0 . 0}$ \\
\hline Count & $\mathbf{9 0 0 . 0}$ & $\mathbf{8 6 0 . 0}$ & $\mathbf{1 4 9 0 . 0}$ \\
\hline
\end{tabular}

TABLE IX: FREQUENCY OF ONLY THOSE LIGHTING ENVIRONMENT AGAinst Which SAMPLE Workers GAVE 'PROPER or AdEQUATE LIGHTING' AS A FEEDBACK

\begin{tabular}{|l|c|c|c|c|}
\hline \multicolumn{1}{|c|}{ Lighting environment } & Bin* & unit 01 & unit 02 & unit 03 \\
\hline Completely Artificial lighting & -2 & 4 & 15 & 2 \\
\hline Mostly Artificial lighting & -1 & 5 & $\mathbf{2 0}$ & 14 \\
\hline Partly Natural lighting & 0 & $\mathbf{3 4}$ & 1 & $\mathbf{1 8}$ \\
\hline
\end{tabular}

* $-2,-1$ and 0 are dummy variables (bin ranges within $-2 \sim 0$ ) for the convenience of statistical analysis.

On the other hand, while considering location of the sample workers in terms of lighting environment or zone, highest numbers of the samples agreed with the proper adequacy of light at their work-plane within partly natural light. In production space-2, highest votes on proper lighting in terms of adequacy were observed for mostly artificial lighting environment, while in both production spaces- 1 and 3 , votes were gained for partly natural environment (Table IX). The Production space configuration in terms of window location, available daylight inside the production space can be one of the reasons behind these variations of the feedback and result.

\section{Comparative Analysis and Results}

The main reasons behind selecting three production spaces and collecting both data of illumination condition and user comfort were to identify the possible visual comfort range for the workers for effective production and visual performance. Within this scope of research, it was found that probable comfort and efficient illumination ranges was commonly 601-800 lux (Table X). As the overall lighting levels in lighting ranges were bit high in production space-3 (Table X), the finding of the ranges became high. But considering the user feedback about brightness and adequacy of light, 601-800 lux were the optimum lighting ranges.

TABLE X: COMPARATIVE ANALySIS BETWEen ThreE Production

\begin{tabular}{|c|c|c|c|c|}
\hline & Terms & $\begin{array}{c}\text { Pro. Unit } \\
-1\end{array}$ & $\begin{array}{c}\text { Pro. } \\
\text { Unit-2 }\end{array}$ & $\begin{array}{c}\text { Pro. } \\
\text { Unit-3 }\end{array}$ \\
\hline \multirow{2}{*}{ Ranges } & $\begin{array}{l}\text { Comfortable } \\
\text { Illuminance ranges in } \\
\text { terms of Adequacy } \\
\text { (Lux) }\end{array}$ & $601-1000$ & $601-800$ & $401-800$ \\
\hline & $\begin{array}{l}\text { Comfortable } \\
\text { Illuminance ranges in } \\
\text { terms of Brightness } \\
\text { (Lux) }\end{array}$ & $601-1000$ & $601-800$ & $401-800$ \\
\hline \multirow{2}{*}{ Mean } & $\begin{array}{l}\text { Mean comfortable } \\
\text { Illuminance in terms of } \\
\text { Adequacy (Lux) }\end{array}$ & 750 & 697 & 763 \\
\hline & $\begin{array}{l}\text { Mean comfortable } \\
\text { Illuminance in terms of } \\
\text { Brightness (Lux) }\end{array}$ & 713 & 675 & 733 \\
\hline \multirow{2}{*}{$\begin{array}{l}\text { Sstandard } \\
\text { deviation }\end{array}$} & $\begin{array}{l}\text { Standard deviation } \\
\text { (comfortable } \\
\text { Illuminance in terms of } \\
\text { Adequacy) }\end{array}$ & 144 & 113 & 241 \\
\hline & $\begin{array}{l}\text { Standard deviation } \\
\text { (comfortable } \\
\text { Illuminance in terms of } \\
\text { brightness) }\end{array}$ & 134 & 95 & 229 \\
\hline $\begin{array}{l}\text { Light } \\
\text { Quality }\end{array}$ & $\begin{array}{l}\text { Major Lighting } \\
\text { environment for proper } \\
\text { lighting }\end{array}$ & $\begin{array}{l}\text { Partly } \\
\text { Natural } \\
\text { light (34) }\end{array}$ & $\begin{array}{l}\text { Mostly } \\
\text { artificial } \\
\text { light (20) }\end{array}$ & $\begin{array}{l}\text { Partly } \\
\text { Natural } \\
\text { light (18) }\end{array}$ \\
\hline Contrast & $\begin{array}{l}\text { User feedback on } \\
\text { uniformity of } \\
\text { illumination between } \\
\text { the worker work-plane } \\
\text { and immediate } \\
\text { surroundings }\end{array}$ & $\begin{array}{l}\text { No } \\
\text { contrast } \\
(85 \%)\end{array}$ & $\begin{array}{l}\text { No } \\
\text { contrast } \\
(75 \%)\end{array}$ & $\begin{array}{l}\text { No } \\
\text { contrast } \\
(57 \%)\end{array}$ \\
\hline Glare & $\begin{array}{l}\text { User feedback on glare } \\
\text { from the source of light } \\
\text { to workers eye while } \\
\text { working }\end{array}$ & $\begin{array}{l}\text { No glare } \\
(93 \%)\end{array}$ & $\begin{array}{l}\text { No glare } \\
(82 \%)\end{array}$ & $\begin{array}{l}\text { No glare } \\
(87 \%)\end{array}$ \\
\hline
\end{tabular}

Considering the mean values and standard deviation from the mean values, it can be said more specifically that the desired illumination level at the work plane of the worker in production spaces to achieve workers comfort should be around 700 lux (within range of 601 800 lux). Considering the quality of lighting, preference of the workers was partly natural or daylight at the work plane (Table X). As natural light is preferable to the workers for visual comfort at the work plane, with efficient lighting design (i.e. positioning of luminaire related to working areas) it is possible to achieve the same visibility conditions with less energy than with incorrect positioning of luminaire causing veiling reflections to the working area.

\section{CONCLUDING REMARKS}

From this research paper, the following specific as well as some general recommendations can be drawn for production spaces of RMG factories in context of Dhaka region in Bangladesh, in order to improve the luminous environment as well as suggest some design guidelines for the architects or designers: 
1) The illumination level at the work-plane of the workers should be within 600-800 lux (average 700Lux) especially for Sewing Operators, Sewing Helper, Quality Controller and others (both male and female) who usually work for 9-10 hours per day in the production spaces of Ready-made garments factories.

2) The lighting condition in conjunction with day lighting is preferable to the worker. Hence, architects should always make daylight provisions along with designing glare controlling devises to add more diffused daylight in indoors.

3) Architects should design the production flow layout within a production space in such a way that the critical works, which require high lighting level to do the work comfortably, can be placed near openings of the production spaces to ensure better luminous environment for the workers.

In conclusion, it can be said that local codes, standards and compliances should be revised with a view to promoting more daylight inclusion and supplement lighting layout with an energy evaluation study for designing efficient production space considering workers health and safety.

\section{ACKNOWLEDGMENT}

The authors acknowledge Bangladesh University of Engineering \& Technology and GIZ for their support.

\section{REFERENCES}

[1] J. R Wilson and N. Corlett, Evaluation of human work, 3rd ed. Taylor and Francis, 2005

[2] Northwast Energy Efficiency Partnership Inc. "Highbay industrial lighting: Knowhow: Combining quality design and energy efficiency for warehouse and factory buildings. (2000). [Online]. Available: http://www.designlights.com.

[3] C. L. Robbins, Daylighting: Design \& analysis, Newyork: Van Nostrand Reinhold Company, 1986.

[4] M. S. Rea and M. J. Ouellette, "Relative visual performance: a basis for application," Lighting Research and Technology, vol. 23, no. 3, pp. 135-144, 1991.

[5] CIE, "The correlation of models for vision and visual performance," CIE (Commission Internationale de l'Éclairage) 2002, pp. 145, 2002.

[6] S. C. Zohir and P. Paul-Majumder, Garment Workers in Bangladesh: Economic, Social and Health Condition, Dhaka: Bangladesh Institute of Development Studies, 2008.
[7] Prokaushali Sangsad Limited, "Energy saving by replacement of magnetic ballasts with electronic ballasts in readymade garments (RMG) factories in Bangladesh," Final Report, GTZ Progress, Bangladesh, 2007.

[8] F. A. Proma, "A neural approach to analysis of work compatibility," M.Sc. Thesis paper (unpublished), Department of Industrial and Production Engineering, Bangladesh University of Engineering and Technology, 2009.

[9] M. M. Hossain and K. S. Ahmed, "Illumination condition and work efficiency in the tropics: study on production spaces of ready-made garments factories in Dhaka," in Proc. 28th International PLEA Conference, Opportunities, Limits \& Needs Towards an Environmentally Responsible Architecture, Lima, Peru, 7 - 9 November 2012.

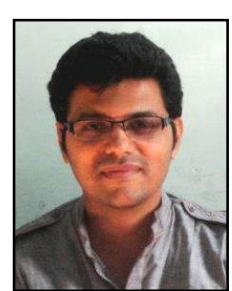

Md Mohataz Hossain was born at Dhaka, Bangladesh in 1983. He obtained bachelor of Architecture and master of Architecture Degree from Bangladesh University of Engineering \& Technology (BUET) on January 2008 and August 2011 respectively. His field of interest is Climate Change, Energy Efficient Built Environment.

He began his professional life through working as an associate architect in two Architectural consultancy offices. He joined as a Lecturer in BUET on September 2008. He has been working as an Assistant Professor at the same university since December 2011. Till now, he has 12 national and international research publications.

Mr Hossain is a candidate member of Institutes of Architects Bangladesh (IAB) since 2008. He is a core member of Green Architecture Cell (GrACe).

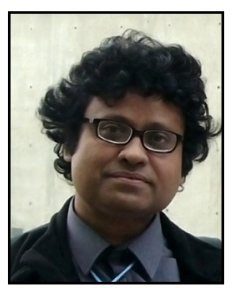

Khandaker Shabbir Ahmed was born in Bangladesh in 1964. He obtained bachelor of Architecture from BUET in 1991. He has got his $\mathrm{PhD}$ in UK at the Architectural Association School of Architecture, London in 1996. He specializes in Bioclimatic Urban Design, low energy buildings for the Tropics with special interests in green building codes, high performance buildings.

$\mathrm{He}$ is a registered architect in Bangladesh and a full professor at the Department of Architecture BUET where he has been teaching for the last 19 years. He has done a number of collaborative research works on the issue and has pioneered environmental simulation based design approach in Bangladesh through professional training, academic studio work, research and own design work. As a member of the editorial committee he has contributed in the upcoming Bangladesh National building Code. 